\title{
Pengaruh Penambahan Abu Bonggol Jagung Pada Tanah Lempung Terhadap Uji California Bearing Ratio
}

\author{
Orlinianto Pasauran ${ }^{\star 1}$, Irwan Lie Keng Wong ${ }^{\star 2}$, Monika Datu Mirring Palinggi ${ }^{\star 3}$ \\ *1 Mahasiswa Program Studi Teknik Sipil, Universitas Kristen Indonesia Paulus, Makassar \\ Email orlinianto169@gmail.com \\ *2 Dosen Program Studi Teknik Sipil, Universitas Kristen Indonesia Paulus, Makassar \\ Email irwanliekengwong@gmail.com \\ *3 Dosen Program Studi Teknik Sipil, Universitas Kristen Indonesia Paulus, MakassarEmail \\ monikadatumirring@gmail.com
}

\begin{abstract}
ABSTRAK
Metodologi dalam penelitian ini adalah melakukan serangkaian pengujian karakteristik tanah kemudian merancang komposisi campuran pengujian Kompaksi (Proctor Standard) untuk mendapatkan nilai kadar air optimum, Pengujian California Bearing Ratio (Unsoaked Design CBR dan Soaked Design CBR) untuk mendapatkan nilai daya dukung tanah. Hasil dari penelitian menunjukkan bahwa tanah memenuhi karakteristik sebagai tanah lempung. Dari pengujian Kompaksi standard pada titik 1 dan titik 2 dengan variasi campuran 0\%, 2,5\%, 5\%, 7,5\%, 10\% mengalami peningkatan pada kadar air optimum dan kepadatan kering makasimum.Pada kadar air optimum pada titik 1 yaitu 21,982\%, 23,210\%, $23,577 \%, 23,813 \%, 24,303 \%$. Sedangkan pada titik 2 yaitu 22,046\%, 22,898\%, 23,200\%, 23,750\%, 24,000\%. Dari pengujian California Bearing Ratio pada Unsoaked Design CBR mengalami peningkatan harga CBR baik titik 1 maupun titik 2 dimana harga CBR titik 1 yaitu 4,967\%, 8,200\%, 9,267\%, 10,167\% sedangkan harga CBR pada titik 2 yaitu 2,200\%, 3,633\%, 4,200\%, 5,300\%, 8,667\%. Untuk Pengujian California Bearing Ratio pada Soaked Design CBR diperoleh harga CBR pada titik 1 yaitu $2,500 \%, 3,100 \%, 5,667 \%, 7,933 \%, 8,567 \%$ sedangkan pada titik 2 yaitu 1,867\%, 2,367\%, 3,700\%, $4,733 \%, 5,367 \%$. Dari hasil penelitian didapatkan bahwa abu bonggol jagung meningkatkan nilai CBR tanah sehingga dapat digunakan untuk meningkatkan daya dukung tanah lempung organik.
\end{abstract}

Kata Kunci : Karakteristik Tanah, Kompaksi, California Bearing Ratio

\begin{abstract}
The methodology in this study is to conduct a series of soil characteristic testing and then design the composition of the Proctor Standard testing mixture to obtain optimum moisture content values, California Bearing Ratio (Unsoaked Design CBR and Soaked Design CBR) to obtain soil support value. The results of the research showed that the soil meets the characteristics as clay soil. From standard compaction testing at point 1 and point 2 with mixed variations of $0 \%, 2.5 \%$, $5 \%, 7.5 \%, 10 \%$ experienced an increase in optimum water content and maximum dry density. Corn weevil ash increases the value of cbr soil so that it can be used to increase the carrying capacity of organic clay soil.
\end{abstract}

Keywords: Soil Characteristics, Compaction, California Bearing Ratio

\section{PENDAHULUAN}

Pada umumnya jenis tanah dapat dibedakan menjadi tanah lempung, tanah pasir dan tanah lanau. Dari ketiga jenis tanah tersebut, tanah lempung dianggap sebagai tanah yang mengalami perubahan ketika kadar air berubah, dan tanah lempung memiliki daya dukung yang rendah. Perbaikan tanah dilakukan pada tanah lempung karena tanah lempung lunak memiliki sifat fisik dan mekanis yang khusus, diantaranya kadar air yang tinggi, angka pori yang besar, berat volume yang kecil, plastisitas indeks yang besar, sehingga ini semua mengakibatkan daya dukung tanah lempung menjadi rendah dan pemampatan yang besar. [1]
Secara teknis tidak layak untuk kontruksi jalan dan bangunan tanpa pondasi dalam. Masalah yang mungkin sering terjadi adalah retak - retak bahkan runtuh, pada jalan terjadi penurunan yang tidak seragam bahkan amblas.

Proses perbaikan tanah secara konvensional saat ini belum mampu merubah sifat kembang susut tanah, sehingga walaupun suatu perkerasan atau konstruksi jalan tersebut sudah dipadatkan, akan cepat mengalami kerusakan dikarenakan sifat-sifat buruk tanah dibawahnya masih ada. Sehingga untuk memperbaiki tanah, salah satu metode perbaikan yang digunakan adalah dengan menambahkan 
bahan pencampuran kimiawi seperti Abu Bonggol Jagung.

CBR merupakan suatu perbandingan antara beban percobaan (test load) dengan beban standar (standard load) dan dinyatakan dalam persen [2]. Nilai CBR adalah nilai yang menyatakan kualitas tanah dasar dibandingkan dengan bahan standar berupa batu pecah yang mempunyai nilai CBR sebesar $100 \%$ dengan memikul beban lalu lintas. Nilai CBR adalah salah satu parameter yang digunakan untuk mengetahui daya dukung tanah dasar dalam perencanaan lapis perkerasan [3] - [4]. Bila tanah dasar memiliki nilai CBR yang tinggi akan mengurangi ketebalan lapis perkerasan yang berada diatas tanah dasar (subgrade). CBR dapat dibagi sesuai dengan cara mendapatkan contoh tanahnya yaitu CBR lapangan (field CBR) dan CBR laboratorium (laboratory $\mathrm{CBR}$ ). CBR laboratorium dibedakan menjadi dua macam yaitu CBR laboratorium rendaman (soaked CBR laboratory dan CBR laboratorium tanpa rendaman (unsoaked CBR laboratory) [5].

Tabel 1 Kriteria CBR untuk tanah dasar jalan (Subgrade)

\begin{tabular}{ccc}
\hline Section & Material & Nilai CBR $(\%)$ \\
\hline \multirow{4}{*}{ Subgrade } & Sangat Baik & $20-30$ \\
& Baik & $10-20$ \\
& Sedang & $5-10$ \\
& Buruk & $<5$ \\
\hline
\end{tabular}

Penelitian sebelumnya yang meneliti bonggol jagung dan CBR antara lain, Effects of Admixtures on the Properties of Corn Cob Ash Cement Concrete [6]. Effects of corn cob ash on lime stabilized lateritic soil [7], Kajian Kuat Desak Dan Modulus Elastisitas Beton Dengan Penambahan Abu Bonggol Jagung Sebagai Zat Additive [8]. Pengaruh Penambahan Abu Bonggol Jagung Terhadap Kuat Tekan Beton K - 200 [9]. Stabilisasi Tanah Lempung Lunak Dengan Memanfaatkan Limbah Gypsum Dan Pengaruhnya Terhadap Nilai California Bearing Ratio (CBR) [10].

Tujuan dari penelitian ini adalah Untuk mengetahui karakteristik tanah pada Desa Marampan Orobua, Kecamatan Sesena padang, Kabupaten Mamasa dan Untuk mengetahui pengaruh penambahan abu bonggol jagung pada tanah lempung terhadap nilai CBR tanah.

\section{METODE}

Lokasi pengambilan material adalah Desa Marampan Orobua, Kecamatan Sesena Padang, Kabupaten Mamasa Lokasi ini terletak $\pm 13 \mathrm{~km}$ dari Kota Mamasa. Lokasi penelitian dapat lihat pada gambar 1.

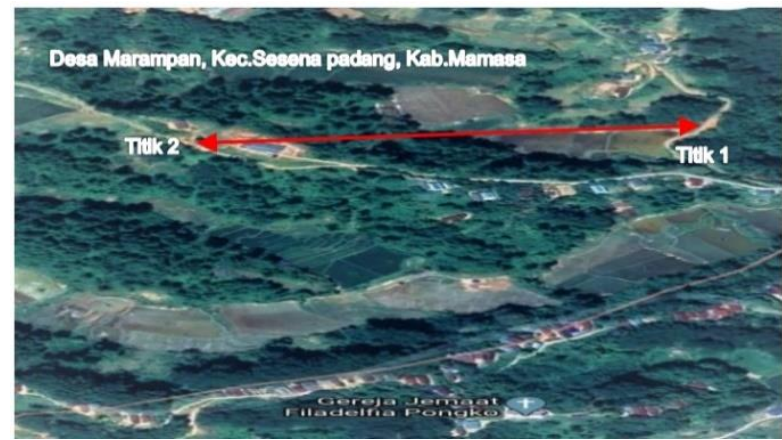

Gambar 1. Lokasi penelitian

\section{Pemeriksaan Karakteristik Tanah}

Pengujian karakteristik tanah dilakukan sesuai dengan metode ASTM (American Standard Testing And Materia).Pengujian tersebut antara lain:

Uji Kadar Air (ASTM D-2216) bertujuan untuk mengetahui jumlah air yang mengisi pori-pori tanah.

Uji Berat Jenis (ASTM 854-58) bertujuan untuk mendapatkan berat jenis tanah sehingga tanah tersebut dapat ditentukan jenis tanahnya melalui nilai berat jenis.

Uji Batas-batas Atterberg (ASTM D 4318-95) bertujuan untuk mendapatkan nilai batas cair (Liquid Limit),batas plastis (Plastic Limit) dan batas susut (Shrinkage Limit)

Uji Analisa Butiran (ASTM D 422-72) dan (ASTM D 1140-54) bertujuan untuk menentukan pembagian butiran dari setiap tanah dan untuk mengetahui berapa besar ukuran butiran setiap tanah.

\section{Pengujian Kompaksi (Standard Proctor)}

Pengujian kompaksi dilakukan menggunakan sampel tanah asli dalam keadaan kering yang dicampur dengan Abu bonggol jagung pada 0\%, 2,5\%, 5\%, $7,5 \%$, dan 10. Hasil pengujian ini berupa kadar air optimum/OMC (Optimum Moisture Content) dan berat volume kering maksimum/MDD (Maximum Dry Density) untuk setiap variasi campuran.

\section{Pengujian California Bearing Ratio}

Pengujian CBR dilakukan dengan dua metode yaitu CBR tanpa rendaman dan CBR rendaman menggunakan sampel tanah asli dalam keadaan kering yang dicampur dengan Abu bonggol jagung pada $0 \%, 2,5 \%, 5 \%, 7,5 \%$, dan $10 \%$. Hasil pengujian ini untuk mengetahui pengaruh penambahan Abu bonggol jagung pada tanah lempung.

\section{Rancangan Benda Uji}

Sampel Benda Uji 
Jumlah benda uji untuk pengujian tiap titik dapat dilihat pada tabel 2 dibawah ini

Tabel 2. Jumlah benda uji

\begin{tabular}{|c|c|c|}
\hline Pengujian & $\begin{array}{l}\text { Benda } \\
\text { uji tiap } \\
\text { titik }\end{array}$ & $\begin{array}{c}\text { Jumlah } \\
\text { benda } \\
\text { uji }\end{array}$ \\
\hline $\begin{array}{l}\text { Pengujian kadar air tanah } \\
\text { asli }\end{array}$ & 3 & 6 \\
\hline Pengujian berat jenis & 2 & 4 \\
\hline Pengujian gradasi & 1 & 2 \\
\hline $\begin{array}{l}\text { Pengujian batas-batas } \\
\text { atterberg }\end{array}$ & & \\
\hline $\begin{array}{l}\text { Pengujian Batas Cair (Liquid } \\
\text { Limit) }\end{array}$ & 4 & 8 \\
\hline $\begin{array}{l}\text { Pengujian Batas Susut } \\
\text { (Plastic Limit) }\end{array}$ & 2 & 4 \\
\hline $\begin{array}{l}\text { Pengujian Batas Plastis } \\
\text { (Shrinkage Limit) }\end{array}$ & 3 & 6 \\
\hline $\begin{array}{l}\text { Pengujian Kompaksi } \\
\text { (Standard Proctor) }\end{array}$ & 25 & 50 \\
\hline $\begin{array}{l}\text { Pengujian } \\
\text { rendaman } \\
\text { Design CBR) }\end{array}$ & 10 & 20 \\
\hline $\begin{array}{l}\text { Pengujian CBR a rendaman } \\
\text { (Soaked Design CBR) }\end{array}$ & 10 & 20 \\
\hline
\end{tabular}

Rancangan variasi campuran pembuatan benda uji kompaksi tiap titik

Tabel 3. Kebutuhan benda uji kompaksi (Standard Compaction Test)

\begin{tabular}{|c|c|c|c|c|c|}
\hline \multirow{2}{*}{ Bahan } & \multicolumn{5}{|c|}{ Persentase Campuran } \\
\hline & $0 \%$ & $2,50 \%$ & $5 \%$ & $7,5 \%$ & $10 \%$ \\
\hline $\begin{array}{l}\text { Kebutuhan } \\
\text { Abu } \\
\text { bonggol } \\
\text { jagung }\end{array}$ & 0 & 125 & 250 & 375 & 500 \\
\hline
\end{tabular}

\begin{tabular}{llllll}
$\begin{array}{l}\text { Kebutuhan } \\
\text { tanah asli }\end{array}$ & 3000 & 3000 & 3000 & 3000 & 3000 \\
\hline
\end{tabular}

Kebutuhan bahan utama uji pemadatan:

Jumlah tanah untuk 1 variasi $=3.000 \mathrm{gr} \times 5$ sampel

$$
=15.000 \mathrm{gram}
$$

Jumlah tanah untuk 5 variasi $=15.000 \mathrm{gr} \times 5$ sampel

$$
=75.000 \mathrm{gram}
$$

Total tanah $=75.000 \mathrm{gr} \times 2=150.000$

Rancangan variasi campuran pembuatan benda uji CBR Unsoaked dan Soaked tiap titik

Tanah asli $=1$ sampel

Tanah + Abu bonggol jagung 2,5\% =1 sampel

Tanah + Abu bonggol jagung 5\% =1 sampel

Tanah + Abu bonggol jagung 7,5\% =1 sampel

Tanah + Abu bonggol jagung 10\% =1 sampel

Tabel 4. Kebutuhan benda uji CBR unsoaked dan soaked

\begin{tabular}{cccccc}
\hline \multirow{2}{*}{ Bahan } & \multicolumn{5}{c}{ Persentase Campuran (\%) } \\
& 0 & 2,5 & 5 & 7,5 & 10 \\
\hline $\begin{array}{c}\text { Kebutuhan Abu } \\
\text { bonggol jagung }\end{array}$ & 0 & 125 & 250 & 375 & 500 \\
$\begin{array}{c}\text { Kebutuhan tanah } \\
\text { asli }\end{array}$ & 5 & 5 & 5 & 5 & 5 \\
\hline
\end{tabular}

\section{HASIL DAN PEMBAHASAN}

1. Hasil Pengujian Karakteristik Tanah

Pengujian karakteristik tanah untuk mengetahui sifatsifat fisis dari tanah asli agar dapat mengetahui jenis tanah tersebut melalui standar spesifikasi. Pengujian karakteristik tanah ini dilakukan di Laboratorium Mekanika Tanah Fakultas Teknik Universitas Kristen Indonesia Paulus. Dari hasil pengujian karakteristik tanah yang telah dilakukan didapatkan hasil masingmasing tiap pengujian sebagai berikut

Tabel 5. Rekapitulasi hasil pengujian karakteristik tanah titik 1

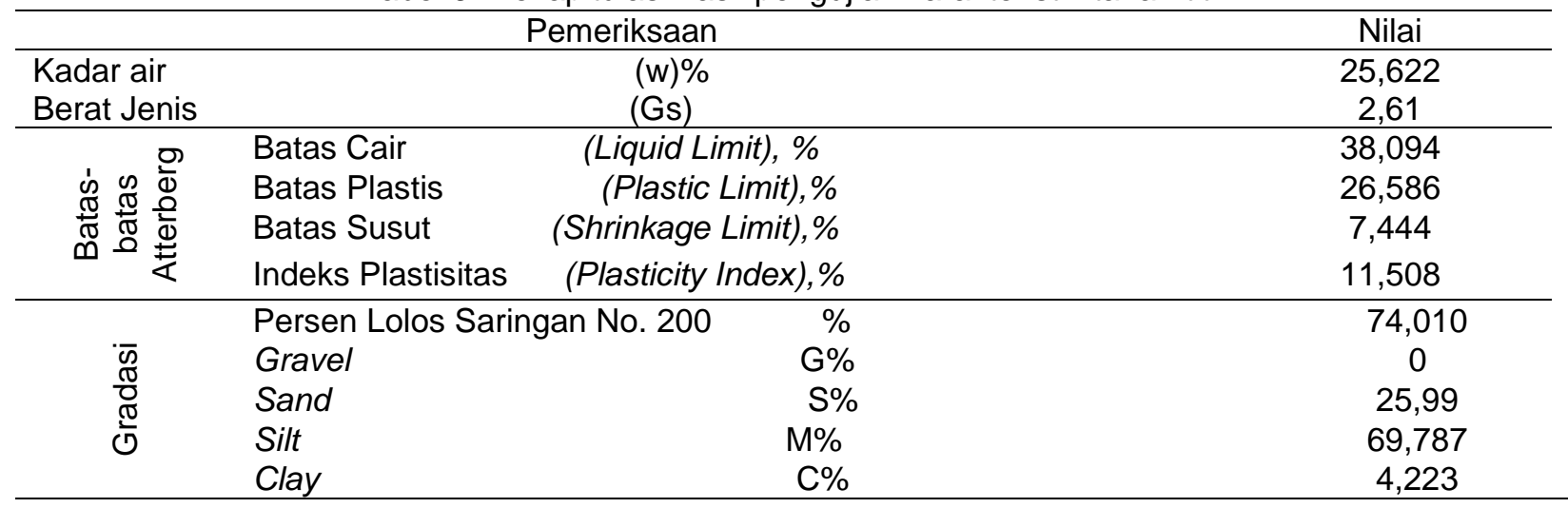


Tabel 6. Rekapitulasi hasil pengujian karakteristik tanah titik 2

\begin{tabular}{|c|c|c|c|}
\hline \multicolumn{3}{|r|}{ Pemeriksaan } & Nilai \\
\hline \multirow{2}{*}{$\begin{array}{l}\text { Kadar air } \\
\text { Berat Jenis }\end{array}$} & \multicolumn{2}{|r|}{$(w) \%$} & 25,622 \\
\hline & \multicolumn{2}{|r|}{ (Gs) } & 2,61 \\
\hline \multirow{4}{*}{ 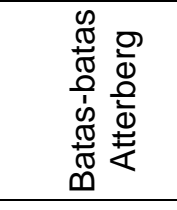 } & Batas Cair & \multirow{3}{*}{$\begin{array}{l}\text { (Liquid Limit), \% } \\
\text { (Plastic Limit),\% } \\
\text { (Shrinkage Limit),\% }\end{array}$} & 38,094 \\
\hline & Batas Plastis & & 26,586 \\
\hline & Batas Susut & & 7,444 \\
\hline & Indeks Plastisitas & (Plasticity Index),\% & 11,508 \\
\hline \multirow{5}{*}{$\begin{array}{l}\bar{y} \\
\frac{\pi}{0} \\
\frac{\pi}{0}\end{array}$} & Persen Lolos Sari & yan No. 200 & 74,010 \\
\hline & Gravel & G\% & 0 \\
\hline & Sand & $\mathrm{S} \%$ & 25,99 \\
\hline & Silt & $\mathrm{M} \%$ & 69,787 \\
\hline & Clay & $\mathrm{C} \%$ & 4,223 \\
\hline
\end{tabular}

\section{Hasil Analisis Karakteristik Tanah}

Pengujian Kadar Air (ASTM D-2216)

Pengujian kadar air tanah asli didapatkan nilai kadar air yang terkandung pada titik 1 sebesar $24,499 \%$ dan titik 2 sebesar 25,622\%.

\section{Pengujian Berat Jenis Tanah (ASTM D 854-58)}

Dari pengujian berat jenis tersebut didapatkan nilai berat jenis pada titik 1 yaitu $2,591 \mathrm{gr} / \mathrm{cm}^{3}$ dan titik 2 yaitu $2,614 \mathrm{gr} / \mathrm{cm}^{3}$.

Angka ini menunjukkan tanah yang telah diteliti termasuk dalam golongan tanah lempung organik.

Pengujian Batas-batas Atterberg (ASTM 4318-95)

Hasil pengujian batas-batas Atterberg pada sampel tanah asli yang telah diteliti di laboratorium mekanika tanah pada pengujian batas cair, batas plastis, dan batas susut dapat dilihat pada Tabel 19. berikut ini:

Tabel 7. Hasil pengujian batas-batas atterberg tanah asli

\begin{tabular}{cccc}
\hline & LL & PL & IP \\
\hline Tanah asli 1 & 39,732 & 26,906 & 12,826 \\
Tanah asli 2 & 38,09 & 26,586 & 11,508 \\
\hline
\end{tabular}

Pengujian Analisa Saringan (ASTM 422-72) dan Hydrometer (ASTM D 1140-54)

Hasil pengujian yang diperoleh dari perhitungan analisa saringan yaitu nilai persen lolos tiap-tiap saringan yang kemudian dihubungkan dengan diameter saringan sehingga terbentuk sebuah garis yang menandakan bahwa sekian persen tanah berpasir yang diperoleh. Setelah itu, pada analisa hydrometer, diperoleh diameter butir dari pada tanah dan persentase kehalusannya. Kedua hal tersebut lalu dihubungkan pada titik koordinat tiap diameter saringan kemudian menghasilkan bahwa sekian persen tanah yang tergolong lanau dan lempung. Perolehan tanah berpasir, berlanau, dan berlempung bila kita lihat dari Grafik yaitu:

Titik 1

Pasir : $100 \%-69,406 \%=30,594 \%$

Lanau : $100 \%-30,594 \%=62,327 \%$;

Lempung: $100 \%-(62,327 \%+30,594 \%)=7,079 \%$

Titik 2

Pasir : $100 \%-74,010 \%=26,00 \%$

Lanau : $100 \%-26,00 \%=69,777 \%$;

Lempung: $100 \%-(69,78 \%+25,99 \%)=4,223 \%$

3. Hasil Pengujian Kompaksi (Standard Proctor)

Dari hasil pengujian kompaksi yang telah dilakukan didapatkan hasil pada Tabel 8. Sebagai berikut:

Tabel 8. Data untuk konversi ke grafik kompaksi titik 1 variasi $0 \%$

\begin{tabular}{ccc}
\hline $\begin{array}{c}\text { Kadar air } \\
\text { optimum } \\
(\%)\end{array}$ & $\begin{array}{c}\text { Kepadatan Kering } \\
\text { maksimum }\left(\mathrm{Gr} / \mathrm{cm}^{3}\right)\end{array}$ & ZAV \\
\hline 20,401 & 1,061 & 1,695 \\
21,437 & 1,071 & 1,665 \\
22,262 & 1,088 & 1,643 \\
22,828 & 1,071 & 1,628 \\
23,582 & 1,058 & 1,608 \\
\hline
\end{tabular}

Secara grafik, nilai kadar air optimum serta kepadatan kering, diperoleh dengan melihat dimana top dari parabola yang dihasilkan dari grafik hubungan kadar air dan kepadatan kering, lalu dapat ditarik garis lurus secara vertical serta horizontal dari top parabola tersebut, sehingga menghasilkan nilai untuk kadar air optimum sebesar 21,982\% dan kepadatan kering $1,081 \mathrm{gr} / \mathrm{cm}^{3}$. 
Sedangkan secara analisis, nilai untuk kadar air optimum dan kepadatan kering diperoleh dari persamaan linear yang dihasilkan dari grafik diatas, yaitu:

Untuk hubungan antara kadar air dengan ZAV (Zero Air Void), diperoleh persamaan :

$$
\begin{array}{ll}
\mathrm{y} & =-0,0273 \mathrm{x}+2,7202 \\
\text { jika y } & =0, \text { maka: } \\
\mathrm{y} & =-0,0273 \mathrm{x}+2,7202 \\
-2,7202 & =-0,0273 \mathrm{x} \\
\mathrm{x} & =(-2,7202) /(-0,0273) \\
\mathrm{x} & =99,641 \%
\end{array}
$$

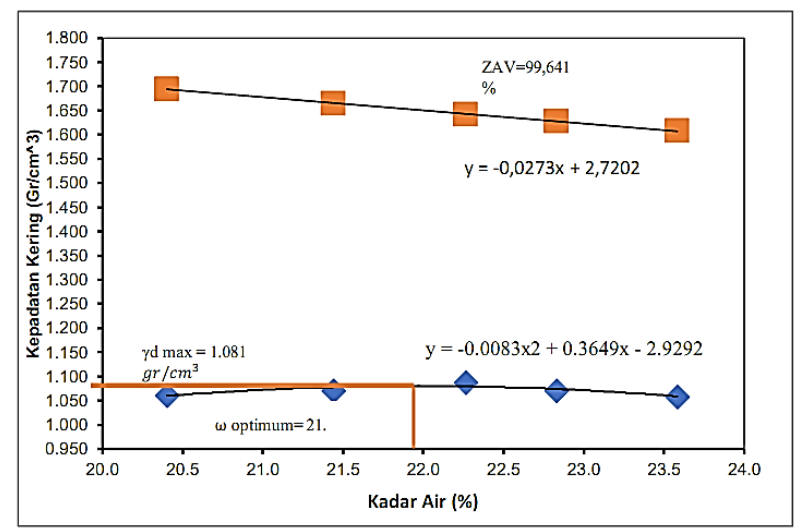

Gambar 2. Grafik kompaksi titik 1 variasi $0 \%$

Sedangkan maksud dari ZAV 100\% menunjukkan bahwa kondisi pori-pori tanah sudah tidak mengandung udara lagi. Diperoleh hasil dari persamaan di atas adalah 99,641\% sedangkan maksud dari ZAV 100\% menunjukkan bahwa kondisi pori-pori tanah sudah tidak mengandung udara lagi. Diperoleh hasil dari persamaan di atas adalah $99,6417 \%$ atau dapat dianggap 100\% udara dalam pori tidak ada.Untuk hubungan antara kadar air dengan kepadatan kering, diperoleh persamaan :

$$
\begin{aligned}
& y d=\llbracket-0,0083 x \rrbracket^{\wedge} 2+0,3649 x-2,9292 \\
& (y d / d w)=-0,0166 x+0,3649 \\
& x=0,3649 / 0,0166=21,982 \% \\
& \text { Dari grafik diperoleh : } \\
& \mathrm{W} \text { opt }=21,982 \% \\
& \mathrm{yd}=\llbracket-0,0083 \mathrm{x} \rrbracket \wedge 20,3649 \mathrm{x}-2,9292 \\
& -0,0083(21,982)^{2}+0,3649(21,982)-2,9292 \\
& =-4,011+8,021-2,9292 \\
& =1,081 \llbracket \mathrm{gr} / \mathrm{cm} \rrbracket^{3}
\end{aligned}
$$

Pada titik 1 penambahan abu bonggol jagung dengan tanah menunjukkan nilai kepadatan kering berbanding lurus dengan persen abu bonggol jagung. Hal ini menandakan bahwa tanah pada titik 1 mengalami peningkatan saat ditambahkan dengan abu bonggol jagung dengan presentase 2,5\% - 10\%.

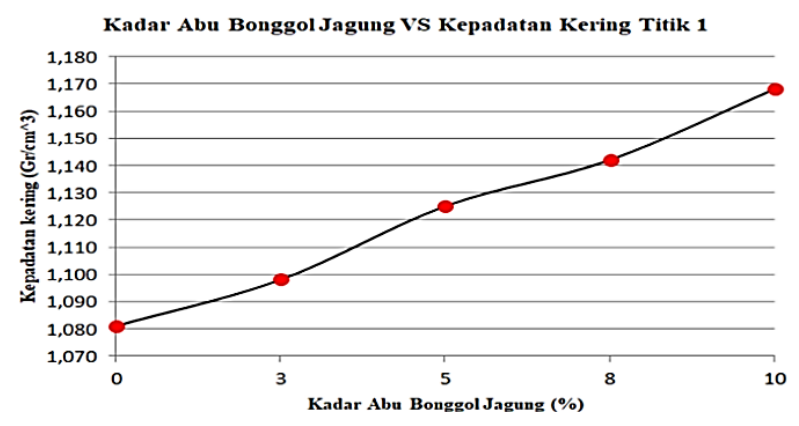

Gambar 3.Hubungan abu bonggol jagung terhadap kepadatan kering titik 1

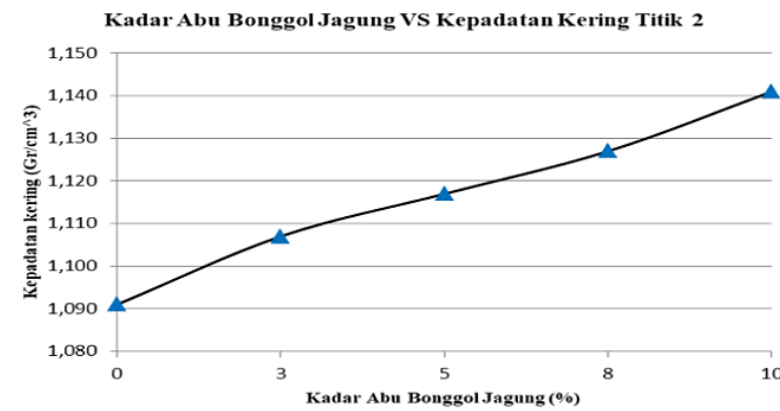

Gambar 4. Hubungan abu bonggol jagung terhadap kepadatan kering titik 2

Pada titik 2 penambahan abu bonggol jagung dengan tanah menunjukkan nilai kepadatan kering berbanding lurus dengan persen abu bonggol jagung. $\mathrm{Hal}$ ini menandakan bahwa tanah pada titik 2 juga mengalami peningkatan saat ditambahkan dengan abu bonggol jagung dengan presentase $2,5 \%-10 \%$.

\section{Hasil Pengujian CBR (California Bearing Ratio)}

CBR Tanpa Rendaman (Unsoaked Design CBR)

Dari hasil pengujian CBR Unsoaked yang telah dilakukan di laboratorium didapatkan hasil pada Gambar 5. sebagai berikut:

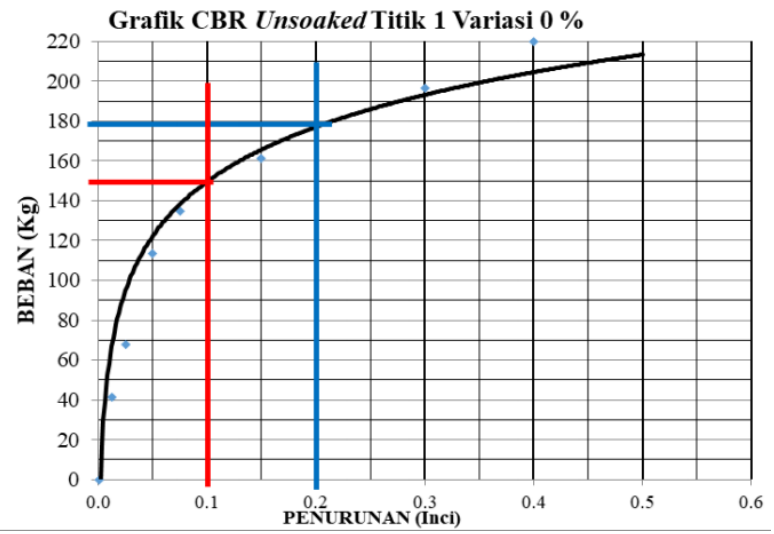


Paulus Civil Engineering Journal

E- Jurnal Teknik Sipil UKI-Paulus Makassar http://ojs.ukipaulus.ac.id/index.php/pcej

Gambar 5. Grafik CBR unsoaked titik 1 variasi 0\%

Pada 0,1" sebesar $145 \mathrm{~kg}$ dan nilai beban pada 0,2" sebesar $170 \mathrm{~kg}$. Setelah nilai beban pada penurunan $0,1^{\text {" dan }} 0,2$ " diperoleh, kemudian menghitung nilai CBR dimana didapatkan nilai CBR pada 0,1 " sebesar $4,833 \%$ dan nilai CBR pada 0,2 " sebesar $3,778 \%$.

Tabel 11. Hasil pengujian CBR unsoaked pada tanah lempung dengan penambahan abu bonggol agung

\begin{tabular}{cccccc}
\hline \multirow{2}{*}{ Keterangan } & \multicolumn{6}{c}{ Kadar Abu Bonggol Jagung (\%) } \\
& 0 & 2,5 & 5,0 & 7,5 & 10 \\
\hline $\begin{array}{c}\text { CBR tanpa } \\
\text { rendaman } \\
\left(\begin{array}{c}\text { Unsoaked) } \\
\text { titik 1 }\end{array}\right.\end{array}$ & 4,9 & 8,2 & 8,7 & 9,2 & 10,1 \\
\hline $\begin{array}{c}\text { CBR tanpa } \\
\text { rendaman } \\
\left(\begin{array}{l}\text { Unsoaked) } \\
\text { titik 2 }\end{array}\right.\end{array}$ & 2,2 & 3,6 & 4,2 & 5,3 & 8,7 \\
\hline
\end{tabular}

Hasil pengujian CBR Unsoaked yang dicampur dengan variasi kadar abu bonggol jagung $0 \%, 2,5 \%$, $5 \%, 7,5 \%$, dan $10 \%$ mengalami peningkatan, pada CBR tanpa rendaman (Unsoaked) titik 1 untuk penambahan $2,5 \%$ nilai CBR 7,60\%, $5 \%$ nilai CBR nya $8,03 \%, 7,5 \%$ nilai CBR 9,17\%, dan $10 \%$ nilai CBR 10,17\%. Begitupun dengan CBR tanpa rendaman (Unsoaked) titik 2 mengalami peningkatan. untuk penambahan $2,5 \%$ nilai CBR $3,43 \%, 5 \%$ nilai CBR $4,13 \%, 7,5 \%$ nilai CBR nya $5,20 \%$, dan $10 \%$ nilai CBR nya $8,67 \%$. Hal ini menunjukkan bahwa penambahan abu bonggol jagung pada sampel tanah meningkatkan nilai CBR tanah.

\section{CBR Tanpa Rendaman (Soaked Design CBR)}

Dari hasil pengujian CBR Soaked yang telah dilakukan di laboratorium didapatkan hasil pada Gambar 6. sebagai berikut:

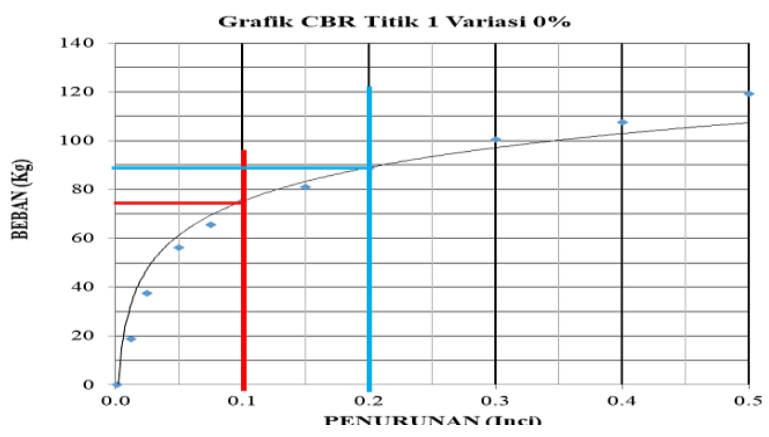

Volume 2 No.4, Desember 2020 ISSN Online : $x x x x-x x x x$
Gambar 6. Grafik CBR soaked titik 1 variasi $0 \%$

Nilai beban pada 0,1 " sebesar $72 \mathrm{~kg}$ dan nilai beban pada 0,2 " sebesar $84 \mathrm{~kg}$. Setelah nilai beban pada penurunan 0,1 "dan 0,2 " diperoleh, kemudian menghitung nilai CBR dimana didapatkan nilai CBR pada 0,1 " sebesar $2,400 \%$ dan nilai CBR pada 0,2 " sebesar $1,867 \%$.

Tabel 13. Hasil pengujian CBR soaked pada tanah lempung dengan penambahan abu bonggol jagung

\begin{tabular}{cccccc} 
& \multicolumn{6}{c}{ Kadar Abu Bonggol Jagung (\%) } \\
Keterangan & 0 & 2,5 & 5,0 & 7,5 & 10 \\
\hline $\begin{array}{c}\text { CBR } \\
\text { rendaman } \\
\text { (Soaked) } \\
\text { titik 1 }\end{array}$ & 2,5 & 3,1 & 5,7 & 7,9 & 8,6 \\
$\begin{array}{c}\text { CBR tanpa } \\
\text { rendaman } \\
\text { (Soaked) } \\
\text { titik 2 }\end{array}$ & 1,9 & 2,4 & 3,7 & 4,7 & 5,4 \\
\hline
\end{tabular}

Hasil pengujian CBR rendaman (Soaked Design CBR) yang dicampur dengan variasi kadar abu bonggol jagung $0 \%, 2,5 \%, 5 \%, 7,5 \%$, dan $10 \%$ mengalami peningkatan, pada CBR rendaman (Soaked Design CBR) titik 1 untuk penambahan 2,5 $\%$ nilai CBR 3,167\%, $5 \%$ nilai CBR 5,500\%, 7,5\% nilai CBR 5,567\%, dan $10 \%$ nilai CBR 7,333\%. Begitupun dengan CBR rendaman (Soaked Design CBR) titik 2 mengalami peningkatan. untuk penambahan 2,5\% nilai CBR 2,267\%, 5\% nilai CBR $3,833 \%, 7,5 \%$ nilai CBR 4,767\%, dan $10 \%$ nilai CBR $5,500 \%$. Hal ini menunjukkan bahwa penambahan abu bonggol jagung pada sampel tanah meningkatkan nilai CBR tanah.

\section{Pengujian Karakteristik Tanah}

Berdasarkan Tabel 14. diperoleh hasil pengujian kadar air sebesar 25,061 \%, Pengujian Berat Jenis sebesar $2,601 \mathrm{gr} / \mathrm{cm}^{3}$ angka ini menunjukkan bahwa tanah ini termasuk tanah lempung organik, Pengujian Batas-batas Atterberg yang terdiri dari Batas Cair yaitu $39,063 \%$, Batas Plastis yaitu $26,746 \%$, Batas Susut yaitu $8,895 \%$, dan Indeks Plastisitas yaitu $12,168 \%$ yang berarti mempunyai sifat plastisitas sedang kohesif. Pengujian Gradasi Analisa Saringan dan Hydrometer, dimana persen lolos saringan No. 200 sebesar $71,708 \%$, dan pengujian Hydrometer didapatkan hasil bahwa sampel tanah tergolong Sand sebesar $28,292 \%$, Silt sebesar $66,057 \%$, dan Clay sebesar 5,651\%. Pada Klasifikasi Tanah untuk Lapisan Dasar Jalan Raya (Sistem AASHTO) tanah 
memenuhi klasifikasi kelompok A-6 karena lebih dari $35 \%$ dari seluruh contoh tanah lolos ayakan No.200 dengan batas cair (Liquid Limit) sebesar 39,063\% dan indeks plastisitas (Plasticity Index) sebesar $12,168 \%$.

Tabel 14. Rekapitulasi rata-rata hasil pengujian karakteristik tanah

\begin{tabular}{|c|c|c|}
\hline \multicolumn{2}{|r|}{ Pemeriksaan } & Nilai \\
\hline \multirow{2}{*}{$\begin{array}{l}\text { Kadar air } \\
\text { Berat Jenis }\end{array}$} & $(w) \%$ & 25,061 \\
\hline & (Gs) & 2,601 \\
\hline \multirow{4}{*}{ 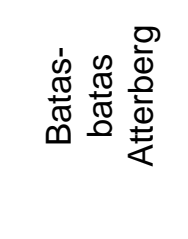 } & (Liquid Limit), & 39,063 \\
\hline & (Plastic Limit), & 26,746 \\
\hline & (Shrinkage Limit), \% & 8,895 \\
\hline & Indeks Plastisitas (Plasticity Index),\% & 12,168 \\
\hline \multirow{5}{*}{$\begin{array}{l}\bar{y} \\
\frac{\pi}{0} \\
\frac{\pi}{\pi} \\
\overline{\mathbb{N}}\end{array}$} & Persen Lolos Saringan No. $200 \%$ & 71,708 \\
\hline & Gravel & 0 \\
\hline & Sand & 28,292 \\
\hline & Silt & 66,057 \\
\hline & Clay & 5,651 \\
\hline
\end{tabular}

Pengujian Pengaruh Abu Bonggol Jagung Terhadap Tanah Lempung

\section{Pengujian Kompaksi (Standard Proctor)}

Berdasarkan hasil uji kompaksi didapatkan kadar air optimum yang akan digunakan pada uji CBR Unsoaked dan Soaked, kadar air optimum (Optimum Moisture Content) dan Kepadatan Kering Maximum (Maximum Dry Density) pada Titik 1 dan Titik 2 mengalami peningkatan tiap variasinya yang dapat dilihat pada Grafik berikut:

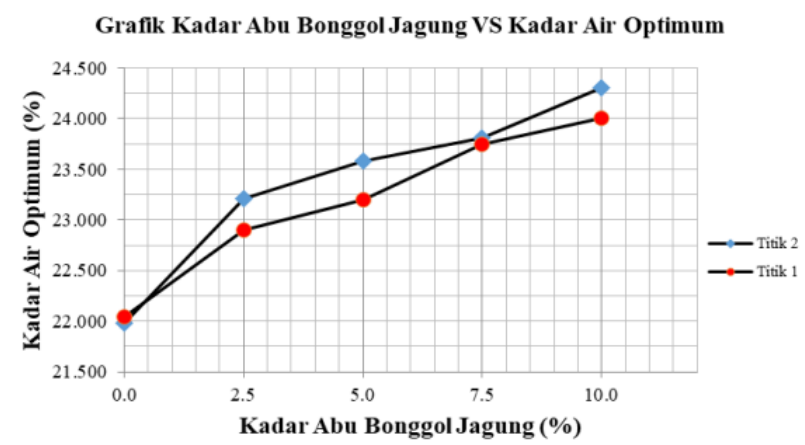

Gambar 7. Grafik kadar abu bonggol jagung terhadap kadar air optimum

Dari Gambar 7 dapat dilihat bahwa kadar abu bonggol jagung berbanding lurus dengan kadar air optimum, dimana semakin tinggi variasi penambahan abu bonggol jagung maka kadar air optimum semakin meningkat.
Grafik Kepadatan Kering Maximum vS Kadar Abu Bonggol Jagung

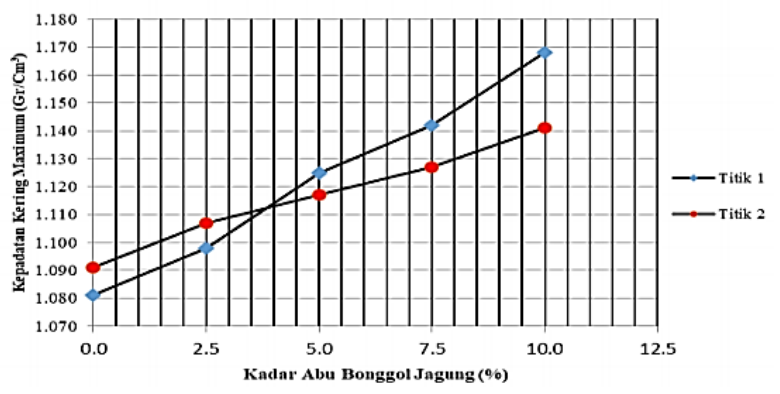

Gambar 8. Grafik kadar abu bonggol jagung terhadap kepadatan kering maksimum

Dari Gambar 8. terlihat bahwa kadar abu bonggol jagung berbanding lurus dengan Kepadatan Kering Maximum, dimana semakin tinggi variasi penambahan abu bonggol jagung maka kepadatan kering maximum semakin meningkat.

Pengujian CBR (California Bearing Ratio) dengan bahan tambah abu bonggol jagung.

Hasil pengujian CBR Tanpa Rendaman (Unsoaked Design CBR)dan CBR Rendaman (Soaked Design CBR) dengan bahan tambah abu bonggol jagung dapat dilihat pada Gambar 9. Dari Gambar 9. dapat dilihat bahwa kadar abu bonggol jagung berbanding lurus dengan nilai CBR baik pada nilai CBR Unsoaked maupun nilai CBR Soaked, dimana semakin tinggi variasi penambahan abu bonggol jagung maka nilai CBR Unsoaked maupun nilai CBR Soaked semakin tinggi. Dari Gambar 9. Grafik Kadar Abu Bonggol Jagung terhadap Nilai CBR nilai CBR Unsoaked tertinggi sebesar $10,17 \%$ memenuhi 
Paulus Civil Engineering Journal

E- Jurnal Teknik Sipil UKI-Paulus Makassar http://ojs.ukipaulus.ac.id/index.php/pcej

kriteria CBR untuk tanah dasar jalan dengan material sedang karena nilai CBR berada pada 5-10\%.

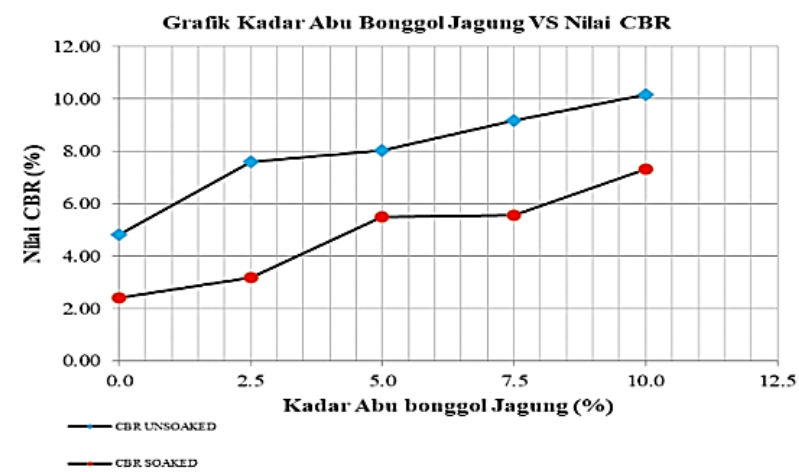

Gambar 9. Grafik kadar abu bonggol jagung terhadap nilai CBR tanah titik 1

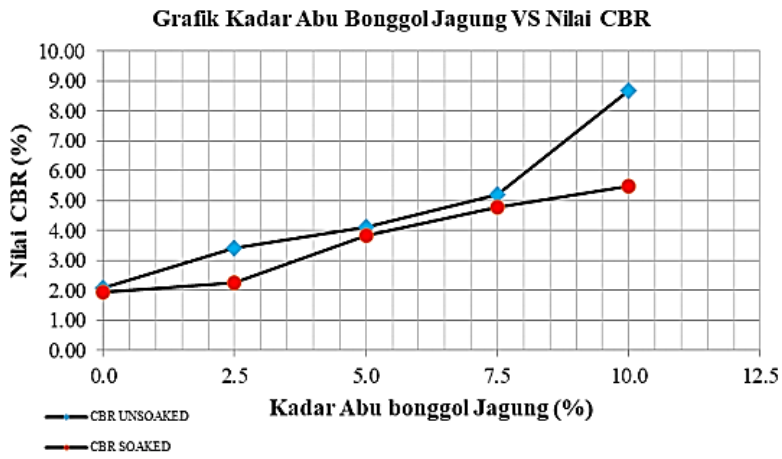

Gambar 10. Grafik kadar abu bonggol jagung terhadap nilai CBR tanah titik 2

Dari Gambar 10 dapat dilihat bahwa kadar abu bonggol jagung berbanding lurus dengan nilai CBR baik pada nilai CBR Unsoaked maupun nilai CBR Soaked, dimana semakin tinggi variasi penambahan abu bonggol jagung maka nilai CBR Unsoaked maupun nilai CBR Soaked semakin tinggi. Dari grafik 10. Grafik Kadar Abu Bonggol Jagung terhadap Nilai CBR, nilai CBR Unsoaked tertinggi sebesar 8,67\% memenuhi kriteria CBR untuk tanah dasar jalan dengan material sedang karena nilai CBR berada pada $5-10 \%$.

\section{KESIMPULAN}

Dari hasil pengujian karakteristik tanah yang berasal dari Desa Marampan Orobua, Kecamatan Sesenapadang, Kabupaten Mamasa, Provinsi Sulawesi Barat merupakan tanah lempung organik dengan sifat plastisitas tergolong plastisitas sedang kohesif dan pengembangan rendah. Penambahan abu bonggol jagung pada tanah lempung terhadap nilai CBR tanpa rendaman (Unsoaked Design CBR) dengan penambahan abu bonggol jagung dari kedua titik memenuhi Kriteria CBR untuk Tanah Dasar
Volume 2 No.4, Desember 2020

ISSN Online : $x x x x-x x x x$
Jalan dimana hasil penelitian dikategorikan sebagai material sedang

Pada CBR rendaman (Soaked Design CBR) didapatkan bahwa semakin tinggi variasi kadar abu bonggol jagung maka pengembangannya semakin kecil sehingga dapat disimpulkan bahwa abu bonggol jagung mempengaruhi kepadatan tanah sehingga semakin tinggi variasi kadar abu bonggol jagung maka pengembangannya semakin kecil. Harga CBR Unsoaked dan CBR Soaked dengan bahan tambah abu bonggol jagung dipengaruhi dari kadar air optimum masingmasing sampel yang didapatkan dari percobaan kompaksi dimana semakin besar nilai kadar air optimum tiap sampel maka harga CBR akan semakin meningkat. Untuk tanah lempung organik dapat menggunakan abu bonggol jagung sebagai bahan tambah untuk meningkatkan daya dukung tanah karena dari hasil penelitian didapatkan bahwa sampel tanah memenuhi karakteristik sebagai tanah lempung dan didapatkan bahwa abu bonggol jagung meningkatkan nilai CBR tanah.

\section{DAFTAR PUSTAKA}

[1] J. E. Bowles dan J. K. Hainim , 2008, Sifat-sifat Fisis dan Geoteknis Tanah, Edisi Kedua. Jakarta Indonesia: Erlangga,

[2] M. D. Braja, 1995, Mekanika Tanah (Prinsipprinsip Rekayasa Geoteknis), vol. 2. Jakarta: Erlangga,

[3] D. Pasole, J. Patanduk, dan I. L. K. Wong, 2020 "Analisis Stabilitas Lereng Disposal Menggunakan Metode Bishop, Janbu, dan Ordinary," Paulus Civ. Eng. J., vol. 2, no. 3, hlm. 144-153,

[4] G. K. Bumbungan, J. Patanduk, dan I. L. K. Wong, 2020 "Pengaruh Penambahan Abu Batubara Terhadap Hasil Uji Kompaksi (Studi Kasus Tanah Lempung Toraja Utara)," Paulus Civ. Eng. J., vol. 3, no. 2, hlm. 180-186

[5] H. C. Hardiyatmo, 2002, Mekanika Tanah I, 3 ed. Yogyakarta: Gajah Mada University Press.

[6] A. A. Raheem, S. O. Oyebisi, S. O. Akintayo, dan M. I. Oyeniran, 2010, "Effects of Admixtures on the Properties of Corn Cob Ash Cement Concrete," Leonardo Electron. J. Pract. Technol., vol. 1, no. 16, hlm. 13-20.

[7] E. S. Nnochir, 2018, "Effects of corn cob ash on lime stabilized lateritic soil," J. Civ. Eng., no. Special Issue, hlm. 73-85.

[8] R. A. Chandra, 2013, "Kajian Kuat Desak Dan Modulus Elastisitas Beton Dengan Penambahan Abu Bonggol Jagung Sebagai 
Paulus Civil Engineering Journal

E- Jurnal Teknik Sipil UKI-Paulus Makassar

http://ojs.ukipaulus.ac.id/index.php/pcei

Zat Additive," Skripsi, Program Studi Teknik Sipil Fakultas Teknik Universitas Atma Jaya Yogyakarta, Yogyakarta.

[9] R. Hepiyanto dan Firdaus Mohammad Arif, 2019, "Pengaruh Penambahan Abu Bonggol Jagung Terhadap Kuat Tekan Beton K - 200," UkaRsT, vol. 3, no. 2, hlm. 86-93.
Volume 2 No.4, Desember 2020

ISSN Online : $x x x x-x x x x$

[10] I. K. Rama, E. Mina, dan N. Fakhri, 2018 "Stabilisasi Tanah Lempung Lunak Dengan Memanfaatkan Limbah Gypsum Dan Pengaruhnya Terhadap Nilai California Bearing Ratio (CBR)," J. Fondasi, vol. 7, no. 1, hlm. 22-31. 